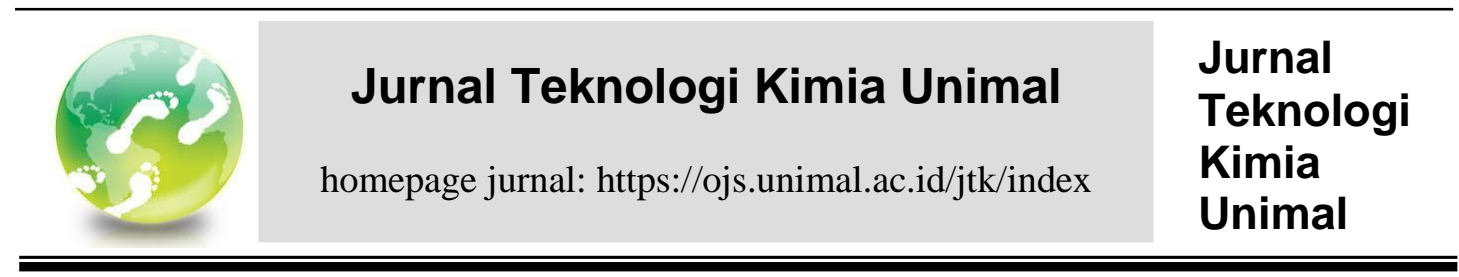

\title{
PERBAIKAN SIFAT MEKANIK DAN LAJU TRANSMISI UAP AIR EDIBLE FILM BIOPLASTIK MENGGUNAKAN MINYAK SAWIT DAN PLASTICIZER GLISEROL BERBASIS PATI SAGU
}

\author{
Rozanna Dewi ${ }^{1}$, Rahmi $^{1}$, Nasrun ${ }^{1}$ \\ ${ }^{1}$ Jurusan Teknik Kimia, Fakultas Teknik, Universitas Malikussaleh \\ Aceh, Indonesia \\ Korespondensi: e-mail: rahmimi564@gmail.com
}

\begin{abstract}
Abstrak
Edible film merupakan suatu lapisan tipis yang terbuat dari bahan-bahan yang dapat dikonsumsi dan digunakan untuk mengemas produk pangan. Edible film yang baik yaitu edible film yang memiliki nilai kuat tarik yang tinggi dan laju trasnmisi uap air yang rendah sehingga edible film mampu melindungi makanan dari gangguan mekanis dengan baik. Penelitian ini dilaksanakan di Laboratorium Teknik Kimia Fakultas Teknik Universitas Malikussaleh, pada bulan oktoberfebruari tahun 2019 dengan tujuan untuk memperbaiki sifat mekanik dan laju trasnmisi uap air edible film menggunakan minyak sawit dan plasticizer gliserol. Proses pembuatan edible film terdiri dari pecampuran bahan, pembentukan gel, pencetakan dan pengeringan. Pengamatan meliputi sifat mekanik dan sifat laju trasnmisi uap air edible film. Hasil penelitian menunjukkan bahwa uji kuat tarik yang didapat berturut-turut adalah 22.947 Mpa, 33.146 Mpa, $37.461 \mathrm{Mpa}$, dan 30.792 Mpa. Persen pemanjangan didapat berturut-turut adalah $313 \%$, $440 \%$, $484 \%$, dan $354 \%$. Nilai laju transmisi uap air tertinggi adalah 3,42 g.m . $^{-2}$.hari ${ }^{-1}$ dan terendah sebesar $1,34 \mathrm{~g} \cdot \mathrm{m}^{-}{ }^{2}$.hari- ${ }^{1}$. Uji kuat tarik yang terbaik didapat pada sampel edible-3 adalah 37,461 Mpa. Persen pemanjangan terbaik yaitu pada sampel edible-2 adalah $484 \%$. Semakin kecil nilai laju transmisi uap air yang diperoleh maka ketahanan edible film terhadap uap air akan semakin bagus.
\end{abstract}

Kata kunci: $\quad$ edible film, plasticizer gliserol, laju transmisi uap air, minyak sawit

\section{Pendahuluan}

\subsection{Latar belakang}

Menurut Darini dkk. (2009), edible film merupakan alternatif untuk menggantikan plastik kemasan karena bersifat biodegradable sekaligus bertindak sebagai barrier untuk mengendalikan transfer uap air, pengambilan oksigen, dan transfer lipid. Edible film juga dapat digunakan untuk melapisi produk yang berfungsi sebagai pelindung dari kerusakan secara mekanis dan aman dikonsumsi. 
Pengembangan edible film sebagai bahan kemasan pangan yang aman untuk dikonsumsi oleh manusia terus mengalami peningkatan dari tahun ke tahun.

Edible film merupakan bahan kemasan pangan yang berbentuk seperti plastik yang terbuat dari bahan biopolimer dan aman dikonsumsi oleh manusia. Bahan polimer edible film terdiri atas tiga golongan, yaitu hidrokoloid, lipida, dan komposit. Hidrokoloid memiliki kelebihan terutama daya rekat terhadap bahan pangan yang dikemas, namun memiliki kelemahan terhadap transmisi uap air. Contoh bahan polimer hidrokoloid adalah pati, pektin dan protein. Lipida memiliki kelebihan dalam menahan laju transmisi uap air, namun bersifat kaku dan mudah retak. Pati merupakan salah satu polimer yang karakteristiknya menyerupai plastik dan salah satu jenis polisakarida yang tersedia melimpah di alam, bersifat mudah terurai (biodegradable), mudah diperoleh, dan murah. Pati sagu memiliki kelebihan sebagai bahan dasar pembuatan biodegradable film karena mudah tergelatinisasi pada suhu rendah, memiliki viskositas yang tinggi, mudah untuk dicetak dan sineresisnya rendah (Anggraeni, 2011). Pati sagu mempunyai potensi untuk dikembangkan sebagai bahan dasar edible film.

Pati sagu sebagai edible film sudah diteliti sebelumnya oleh Vina rosadi (2016), dimana pati sagu dicampurkan dengan ekstrak wortel. Film berbahan pati dan pektin memiliki elastisitas tinggi, tetapi bersifat rapuh sehingga mudah patah (Abdorreza et al., 2011) dan hidrofilik (sangat sensitif terhadap air). Menurut Kester dan Fennema (1986), Hernandez (1994); untuk memperbaiki kelemahan edible film tersebut dapat dilakukan dengan penambahan lipida dan plasticizer dalam formulasi film tersebut.

Menurut Tanaka (Santoso, 2017) bahwa penambahan asam lemak tidak jenuh pada larutan memberikan pengaruh yang signifikan dalam menurunkan laju transmisi uap air edible film. Manab (Santoso, 2017) melaporkan bahwa penambahan minyak sawit sebesar $10 \%$ dapat menurunkan laju transmisi uap air. Penambahan plasticizer pada edible film ini penting untuk mengatasi sifat rapuh film yang disebabkan kekuatan intermolekul ekstensif.

Pada penelitian ini peneliti akan mengganti ekstrak wortel dengan bahan baku yang berasal dari lipida yaitu berupa minyak kelapa sawit dengan 
penambahan platilizer gliserol. Pada penelitian ini akan dikaji pengaruh penambahan gambir dan Plasticizer Gliserol dalam memperbaiki sifat mekanik dan pengaruh penambahan minyak sawit dapat menurunkan laju transmisi uap air pada edible film.

\subsection{Perumusan masalah}

1. Bagaimana pengaruh penambahan gambir dan Plasticizer Gliserol dapat memperbaiki sifat mekanik edible film?

2. Bagaimana pengaruh penambahan minyak sawit dapat menurunkan laju transmisi uap air pada edible film?

\subsection{Tujuan penelitian}

1. Untuk memperbaiki sifat mekanik edible film memanfaatkan gambir dan platicizer gliserol.

2. Untuk memperbaiki sifat laju transmisi uap air edible film berbasis pati sagu dengan memanfaatkan minyak sawit.

\subsection{Manfaat penelitian}

Manfaat yang dapat diperoleh dari penelitian ini adalah dapat menemukan bahan baku lain pembuatan edible film dalam memperbaiki sifat laju transmisi uap air dan sifat mekanik edible film, meningkatkan ketahanan edible film terhadap uap air dan dapat melindungi makanan yang dikemas dari kerusakan mekanik sehingga dapat bertahan lama serta makanan yang dikemas tidak megalami pembusukan.

\subsection{Batasan penelitian}

Ruang lingkup penelitian ini adalah menganalisa laju transmisi uap air, persen pemanjangan dan kuat tarik pada edible film.

\section{Tinjauan Pustaka}

\subsection{Sagu}

Tepung sagu mengandung amilosa $27 \%$ dan amilopektm $73 \%$. Kestabilan edible film dipengaruhi oleh amilopektin, sedangkan amilosa berpengaruh 
terhadap kekompakannya. Pati dengan kadar amilosa tinggi menghasilkan edible film yang lentur dan kuat karena struktur amilosa memungkinkan pembentukan ikatan hidrogen antarmolekul glukosa penyusunnya dan selama pemanasan mampu membentuk jaringan tiga dimensi yang dapat memerangkap air sehingga menghasilkan gel yang kuat (Rahmi Yulianti Purwitasari 2001).

Tabel 1 Komposisi kimia pati sagu

\begin{tabular}{|c|c|}
\hline Komponen & Jumlah (\%) \\
\hline Air & 12,0 \\
\hline Protein & 0,7 \\
\hline Abu & 0,1 \\
\hline Lemak & 3,0 \\
\hline Serat & 0,2 \\
\hline Amilosa & 22,97 \\
\hline Amilopektin & 62,11 \\
\hline
\end{tabular}

Sumber: Richana, dkk., (2000)

\subsection{Pati sebagai Biofilm}

Bahan dasar pembuatan edible film adalah pati. Pati merupakan senyawa yang tersusun dari polisakarida (karbohidrat), polipeptida (protein) dan lipida. Ketiga komponen penyusun pati tersebut memiliki sifat termoplastik, sehingga mempunyai potensi untuk dibentuk atau dicetak sebagai film kemasan. Salah satu keunggulan bahan polimer ini adalah bahannya yang berasal dari sumber terbarui yang dapat dihancurkan secara alami atau biodegradable. Pati sering digunakan dalam industri pangan sebagai biodegradable film untuk menggantikan polimer plastik karena ekonomis, dapat diperbaharui, dan memberikan karakteristik fisik yang baik.

\subsection{Plasticizer}

Plasticizer didefinisikan sebagai bahan non volatil, bertitik didih tinggi jika ditambahkan pada material lain dan dapat merubah sifat material tersebut. Penambahan plasticizer dapat menurunkan kekuatan intermolekuler, meningkatkan fleksibilitas film dan menurunkan sifat barrier film. Plasticizer 
ditambahkan pada pembuatan edible film untuk mengurangi kerapuhan meningkatkan fleksibilitas dan ketahanan film terutama jika disimpan pada suhu rendah.

Beberapa jenis plasticizer yang dapat digunakan dalam pembuatan edible film adalah gliserol, lebah, polivinil alkohol, sorbitol, asam laurat, asam oktanoat, asam laktat, trietilen glikol, polietilen glikol,acetylated monoglyceride (Acetem).

\subsection{Plasticizer Gliserol}

Gliserol efektif digunakan sebagai plasticizer pada film hidrofilik, seperti film berbahan dasar pati, gelatin, pektin, dan karbohidrat lainnya termasuk khitosan. Penambahan gliserol akan menghasilkan film yang lebih fleksibel dan halus. Gliserol adalah molekul hidrofilik yang relativ kecil dan dapat dengan mudah disisipkan di antara rantai protein dan membentuk ikatan hidrogen dengan amida. Gliserol dapat meningkatkan pengikatan air pada edible film.

\subsection{Minyak Sawit}

Penggunaan minyak sawit bertujuan untuk memperbaiki karakteristik dari edible film. Edible film yang terbuat dari pati memiliki kelemahan yaitu resistensinya terhadap uap air rendah karena pati bersifat hidrofilik dimana dapat mempengaruhi stabilitas dan sifat mekanisnya (Garcia et al., 2011). Penambahan konsentrasi lipid yang lebih rendah (5\%) menghasilkan nilai tensile strength yang lebih tinggi dibandingkan dengan penambahan lipid yang tinggi (15\% dan 20\%) (Pangesti et al., 2014).

\subsection{Gambir}

Gambir adalah ekstrak air panas dari daun dan ranting tanaman gambir yang diendapkan dan kemudian dicetak dan dikeringkan, yang berfungsi sebagai astringen. Kandungan utama ekstrak Gambir adalah katekin sekitar 7-33\%,dan. Selain katekin ekstrak Gambir mengandung bermacam-macam komponen, Antara lain: Asam kathechu tannat 20-55 \%, pyrokatechol 20-30\%, gambir floresen 1-3 $\%$, katechu merah 35\%, quersetin 2-4 \%, Fixed oil 1,2 \% dan wax 1-2 \%. Salah satu yang termasuk dalam senyawa polifenol adalah flavanoid. 
Komponen fitokimia terbanyak pada daun gambir ialah flavonoid dengan komponen utamanya katekin sebesar 75\%, yang mampu menghambat atau membunuh pertumbuhan bakteri patogen penyebab kerusakan pangan, seperti Escherichia coli ATCC 25922, Salmonella typhimurium,Staphylococcus aureus ATCC 29213 dan Bacillus cereus (Vensia Novi M, 2015).

\subsection{Edible film}

Secara umum edible film dapat didefinisikan sebagai lapis tipis yang melapisi suatu bahan pangan dan layak dimakan, digunakan pada makanan dengan cara pembungkusan. edible film dapat digunakan untuk memperbaiki kualitas makanan, memperpanjang masa simpan, meningkatkan efisiensi ekonomis, menghambat perpindahan uap air (Krochta,1992).

\subsection{Bahan baku edible film}

Edible film dapat dibedakan dalam tiga kategori berdasarkan bahan baku yang digunakan yaitu hidrokoloid, lemak dan campuran keduanya. Golongan hidrokoloid dapat dibuat dari polisakarida (selulosa, modifikasi selulosa, pati, agar, alginat, pektin, dekstrin), protein (kolagen, gelatin, putih telur), termasuk golongan lipid. Edible film campuran terdiri dari campuran lipid dan hidrokoloid serta mampu menutupi kelemahan masing-masing (Guilbert,1990).

\subsection{Sifat -Sifat Edible film.}

\section{Uji Tarik}

Kuat tarik merupakan tarikan maksimum yang dapat dicapai sampai film dapat tetap bertahan sebelum putus. Pengukuran tensile strength untuk mengetahui besarnya gaya yang dicapai untuk mencapai tarikan maksimum pada setiap satuan luas area film untuk merenggang atau memanjang (Purwanti, 2010). Perubahan sifat mekanik ditandai dengan plasticizer melemahnya gaya antarmolekul antara rantai makromolekul yang berdekatan (Bourtoom, 2007).

\section{Persen Permanjangan}

Persen pemanjangan merupakan perubahan panjang maksimum pada saat terjadi peregangan hingga film terputus. Umumnya plasticizer dalam jumlah lebih 
besar akan membuat nilai persen pemanjangan suatu film meningkat lebih besar biodegradable film sebesar 10-20\% menurut standar plastik internasional. Kekuatan perengangan mengambarkan tekanan maksimum yang dapat diterima oleh bahan atau sampel.

\section{Permeabilitas Uap air (WVTR).}

Polimer dengan polaritas tinggi (polisakarida dan protein) umumnya menghasilkan nilai permeabilitas uap air yang tinggi dan permeabilitas terhadap oksigen rendah. Hal ini disebabkan karena polimer mempunyai ikatan hidrogen yang besar. Sebaliknya, polimer yang bersifat non polar (lipida) yang banyak mengandung gugus hidroksil mempunyai nilai permeabilitas uap air rendah dan permeabilitas oksigen yang tinggi, sehingga menjadi penahan air yang baik tetapi tidak efektif menahan gas.

\section{METODOLOGI PENELITIAN}

\subsection{Tempat dan Waktu Penelitian}

Adapun tempat penelitian ini dilakukan di laboratorium Teknik Kimia Fakultas Teknik Universitas Malikussaleh dan analisa Uji mekanis akan dilakukan di laboratorium Teknik Kimia Unsyiah. Adapun waktu pelaksanaan penelitian ini dimulai pada bulan September 2018.

\subsection{Peralatan dan Bahan yang Digunakan}

peralatan yang di gunakan: (1) Testing machine, (2 )Cawan porselen, (3) Casting kaca, (4) Desikator, (5) Gelas kimia $100 \mathrm{~mL}$, (6)Termometer, (7) pH meter, (8) Magnetic stirrer, (9) Oven pengering, (10) Hot plate, (11) Gelas beaker $500 \mathrm{ml}$, (12) Spatula, (13) Timbangan analitik.

Bahan-bahan yang di gunakan: (1) Pati sagu, (2) Gambir, (3) Gliserol, (4) Aquades, (5) Minyak sawit, (6) Jeruk kasturi.

\subsection{Variabel Penelitian}

\section{Variabel Tetap}


Berat sagu : 50 gram, Volume Aquades : $300 \mathrm{~mL}$, Platilizer Gliserol : 9 mL, Suhu gelatinisasi : 700C

\section{Variabel Bebas}

Berat ekstrak Gambir : 4,5 dan 9 gram, Minyak sawit: 4,5 dan $9 \mathrm{ml}, \mathrm{pH}$ suspensi: 3 dan 4 .

\section{Variabel Terikat}

Uji Laju transmisi uap air, Uji persen pemanjangan, Uji kuat tarik.

\subsection{Prosedur Penelitian}

\section{Pembuatan Sari Buah Jeruk Kasturi}

Disortasi jeruk kasturi atau dipilih yang sudah matang. Dicuci menggunakan air bersih dan ditiriskan. Dikupas dan dibuang bijinya. Diperas dengan menggunakan alat peras jeruk.Disaring sari jeruk kasturi menggunakan saringan.

\section{Pembuatan Edible Film}

Dimasukkan ke dalam beaker gelas pati sagu sebanyak 50 gram. Ditambahkan aquades sampai batas $300 \mathrm{~mL}$. Dipanaskan menggunakan hot plate pada suhu 700C sampai terjadi gelatinalisasi. Diaduk menggunakan magnetic stirrer pada kecepatan $300 \mathrm{rpm}$. Ditambahkan gliserol sebanyak $9 \mathrm{ml}$. Ditambahkan sari jeruk kasturi sesuai perlakuan tingkatan ph (3 dan 4). Ditambahkan gambir sesuai dengan perlakuan (4,5 gr dan 9 gr) sedikit demi sedikit dan diaduk sampai homogen. Ditambahkan minyak sawit sesuai perlakuan $(4,5 \mathrm{~mL}$ dan $9 \mathrm{~mL})$. Dicetak dalam Casting kaca dengan diameter $20 \times 20 \mathrm{~cm}$ dan diratakan.Dikeringkan dalam oven pengering dengan suhu 700C selama 24 jam. Diangkat Edible film dan diletakkan dalam desikator selama 24 jam dan siap untuk dianalisa.

\section{Analisa Edible Film}

Laju transmisi uap air (ASTM E96-01, 1997) 
Diukur laju trasmisi uap air dengan metode cawan yang ditentukan secara gravimetri. Dipotong edible film dengan bentuk lingkaran dengan diameter sesuai permukaan cawan. Ditimbang berat awal cawan dan dimasukkan 3 gram silika gel. Diikat edible film pada cawan yang berisi silika gel. Dilapisi lilin cair pada permukaan edible film. Dikondisikan dalam suhu ruangan selama 24 jam. Ditimbang berat akhir sampel dan dihitung menggunakan rumus:

$\mathrm{WVTR}=(\mathrm{W}-\mathrm{W} 0) /(\mathrm{t} \times \mathrm{A})$

Keterangan: $\mathrm{W} 0=$ Berat awal

$$
\begin{aligned}
\mathrm{W} & =\text { Berat akhir setelah } 24 \text { jam } \\
\mathrm{t} & =\text { waktu }(24 \mathrm{jam}) \\
\mathrm{A} & =\text { luas area film }\left(\mathrm{m}^{2}\right)
\end{aligned}
$$

Persen Pemanjangan (elogansi)

Dipotong sampel berbentuk huruf "I" dengan ukuran 7 X $3 \mathrm{Cm}$. Diletakan pada alat analisa dengan diamati panjang awalnya. Dijalankan alat hingga edible film putus dan panjang akhir dicatat. Dihitung menggunakan rumus:

$\%$ Perpanjangan $=\mathrm{P} 1-\mathrm{P} 1 / \mathrm{P} 2 \times 100 \%$

Keterangan: $\mathrm{P} 1=$ panjang awal $\mathrm{P} 2$ = panjang akhir

Kuat Tarik

Dipotong sampel berbentuk huruf "I" dengan ukuran 7 X $3 \mathrm{Cm}$. Diletakan pada alat analisa secara vertikal ke atas dengan diamati luas permukaanya. Dijalankan alat dan dicatat besar gaya tekan edible film. Dihitung menggunakan rumus:

Kuat Tarik $=\mathrm{F} / \mathrm{A}$

Keterangan: $\mathrm{F}=$ Gaya Tekan $(\mathrm{N})$

$$
\mathrm{A}=\text { Luas permukaan (cm2) }
$$

\section{Hasil dan Diskusi}

\subsection{Hasil}


Penelitian ini melakukan beberapa uji untuk mengetahui karakterisasi dari edible film bioplastik pati sagu. Hasil dari kuat tarik, persen perpanjangan, laju transmisi uap air edible film bioplastik dari pati sagu yang dibuat pada penelitian ini. Hasil dari pengujian akan diuraikan di bawah ini.

\section{Uji Mekanis (Tensile dan Elongation)}

Uji mekanis ini dilakukan di Laboratorium MIPA-Fisika Universitas syiah Kuala. Hasil uji Mekanis (Tensile dan Elongation) pada edible film bioplastik dapat dilihat pada Tabel 2.

Tabel 2. Hasil Uji Mekanis dengan Uji Tensile dan Elongation

\begin{tabular}{|l|c|c|c|c|}
\hline Sampel & $\begin{array}{c}\text { Gambir } \\
(\mathbf{g r})\end{array}$ & $\begin{array}{c}\text { Minyak sawit } \\
(\mathbf{m l})\end{array}$ & $\begin{array}{c}\text { Tensile Strenght } \\
(\mathbf{M p a})\end{array}$ & $\begin{array}{c}\text { Elongation } \\
(\mathbf{\%})\end{array}$ \\
\hline Edible-1 & 4,5 & 4,5 & 22.947 & 313 \\
\hline Edible-2 & 4,5 & 9 & 33.146 & 440 \\
\hline Edible-3 & 9 & 4,5 & 37.461 & 484 \\
\hline Edible-4 & 9 & 9 & 30.792 & 354 \\
\hline
\end{tabular}

\section{Uji laju transmisi uap air (WVTR)}

Tabel 3 Hasil Uji laju transmisi uap air edible film

\begin{tabular}{|l|c|c|c|c|}
\hline No sampel & $\begin{array}{c}\text { Gambir } \\
(\mathbf{g r})\end{array}$ & $\begin{array}{c}\text { Minyak Sawit } \\
(\mathbf{M L})\end{array}$ & $\mathbf{p H}$ & $\begin{array}{c}\text { Laju transmisi uap air } \\
\text { (g.m }^{-2} \cdot \mathbf{h a r i}^{\mathbf{1})}\end{array}$ \\
\hline Edible-1 & 4,5 & 4,5 & 3 & 3,28 \\
\hline Edible-2 & 4,5 & 9 & 3 & 1,34 \\
\hline Edible-3 & 9 & 4,5 & 3 & 2,95 \\
\hline Edible-4 & 9 & 9 & 3 & 2,76 \\
\hline Edible-5 & 4,5 & 4,5 & 4 & 3,42 \\
\hline Edible-6 & 4,5 & 9 & 4 & 2,63 \\
\hline Edible-7 & 9 & 4,5 & 4 & 2,40 \\
\hline Edible-8 & 9 & 9 & 4 & 2,69 \\
\hline
\end{tabular}




\subsection{Diskusi}

Edible film bioplastik yang telah kering atau telah jadi kemudian dilakukan pengujian untuk mengetahui karakterisasi dari film plastik dengan melakukan beberapa pengujian.

\section{Uji Mekanis}

\section{Kuat tarik}

Kuat tarik merupakan gaya tarik maksimum yang dapat di tahan oleh sebuah bioplastik hingga terputus. Kuat tarik yang terlalu kecil mengindikasikan bahwa bioplastik yang bersangkutan tidak dapat dijadikan kemasan, karena karakter fisiknya kurang kuat dan mudah patah. Pengujian dilakukan dengan cara pemberian beban pada bioplastik yang kemudian bioplastik ditarik hingga putus. Pengukuran ini untuk mengetahui besarnya gaya yang diperlukan untuk mencapai tarikan maksimum pada setiap luas area film.

Hubungan komposisi gambir dan minyak sawit terhadap hasil kuat tarik dapat dilihat pada Gambar 1.

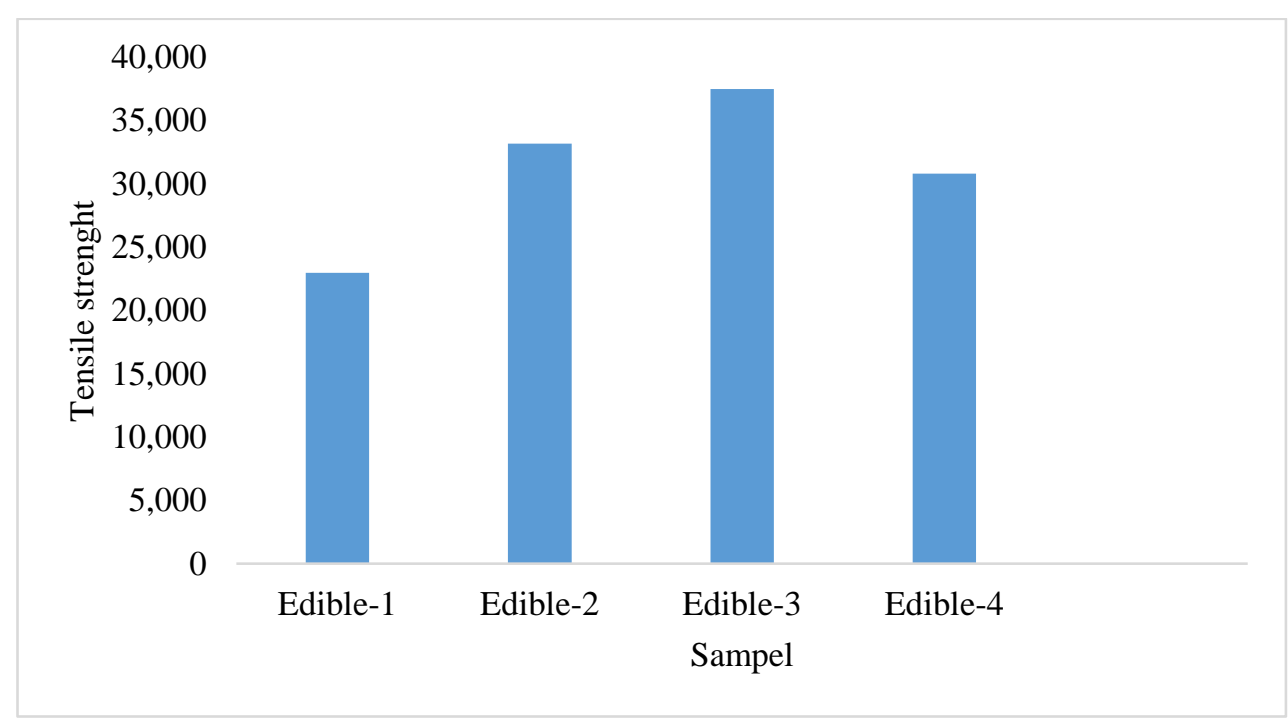

Gambar 1. Hubungan Nilai Kuat Tarik dengan Komposisi Gambir dan Minyak sawit

Gambar 1 menunjukan bahwa pada nilai kuat tarik paling besar pada sampel edible-3 dimana perbandingan 9 gram gambir dan 4,5 minyak sawit adalah 
37,461 Mpa. Santoso (2011) menjelaskan bahwa penggunaan surfaktan dengan konsentrasi dan jenis yang tepat akan mempengaruhi homogenitas suspensi film yang terbentuk. Suspensi film yang homogen akan menghasilkan edible film yang rapat, padat dan rata sehingga berpengaruh terhadap sifat mekanis edible film. Minyak sawit mengandung asam lemak tidak jenuh berbentuk cair pada suhu kamar. Asam lemak tak jenuh memiliki mobilitas yang baik dari ikatan rangkapnya sehingga asam lemak tidak jenuh menyebar merata dalam matrik edible film bioplastik. Hal ini tidak berpengaruh terhadap kuat tekan, namun berpengaruh terjadi penurunan laju transmisi uap air.

Menurut Japanese International Standard (JIS) (1975) nilai kuat tarik edible film bioplastik minimal $3.923 \mathrm{MPa}$. Sedangkan hasil film plastik pada penelitian ini diperoleh nilai kuat tarik berada diatas nilai JIS. Berdasarkan hasil yang telah diperoleh tersebut maka hasil penelitian ini telah terjadi perbaikan sifat kuat tarik.

\section{Persen pemanjangan}

Hubungan komposisi gambir dan minyak sawit terhadap persen pemanjangan dapat dilihat pada Gambar 2.

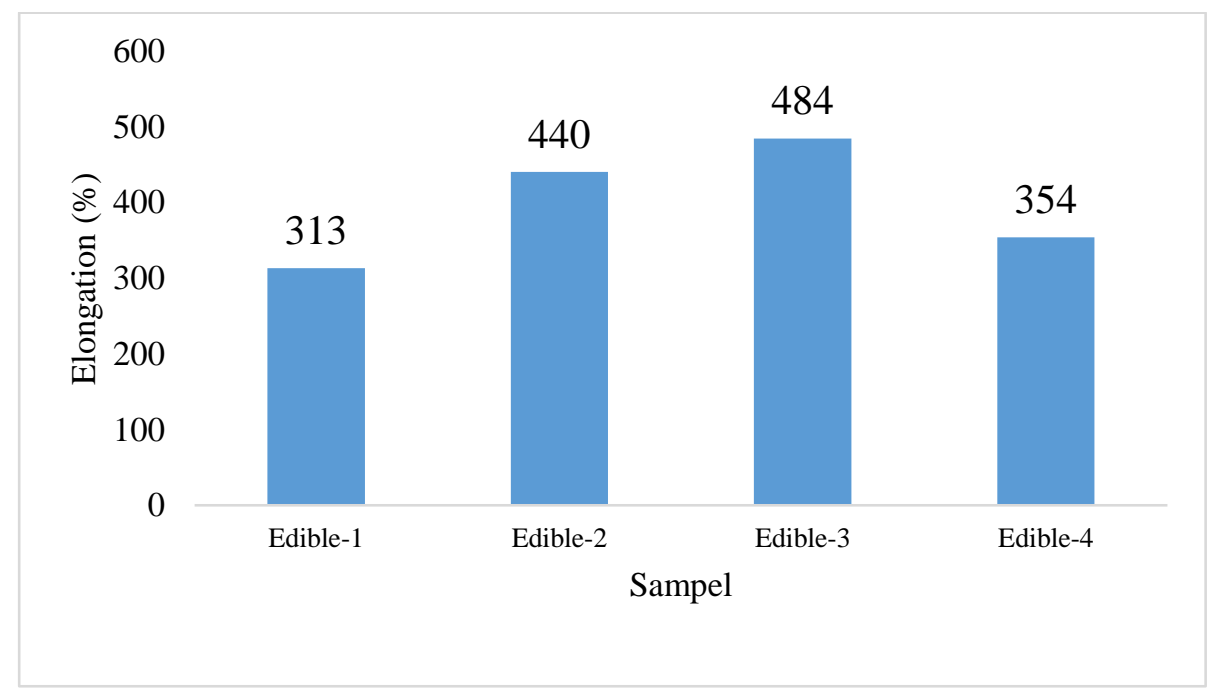

Gambar 2. Hubungan komposisi gambir dan minyak sawit terhadap Persen Pemanjangan 
Gambar 2 menunjukan bahwa \% pemanjangan paling besar yaitu sampel edible-3 dimana perbandingan 9 gram gambir dan 4,5 minyak sawit adalah $484 \%$. Pemanjangan merupakan perubahan panjang maksimum sebelum film terputus. Persen pemanjangan mempresentasikan kemampuan film untuk meregang secara maksimum. Hasil uji seperti pada Tabel 3 menunjukkan bahwa perlakuan penambahan ekstrak gambir konsentrasi satu dengan yang lainnya berbeda nyata terhadap nilai persen pemanjangan. Semakin tinggi konsentrasi ekstrak gambir yang ditambahkan persen pemanjangan semakin meningkat. Hal ini disebabkan senyawa katekin yang dikandung oleh ekstrak gambir memiliki gugus hidroksil $(\mathrm{OH})$ dimana gugus $\mathrm{OH}$ ini dapat mengikat air, sehingga makin tinggi konsentrasi ekstrak gambir maka makin banyak gugus $\mathrm{OH}$ yang dapat mengikat air dalam matrik (Pambayun, 2008) Jumlah air yang terikat dalam matrik berpengaruh terhadap peningkatan elastisitas. Rodriguez dkk. (2006) menjelaskan bahwa gliserol yang banyak mengandung gugus $\mathrm{OH}$ dalam sistem matrik edible dapat meningkatkan laju transmisi uap air dan persen pemanjangan.

Hasil uji menunjukkan bahwa makin tinggi konsentrasi minyak sawit persen pemanjangan edible film makin menurun. Minyak sawit mengandung asam lemak tidak jenuh yang bersifat hidropobik dan berbentuk cair pada suhu kamar. Asam lemak tak jenuh dapat meregulasi asam-asam lemak dalam matrik sehingga merata dan padat yang menyebabkan tingkat elastisitas menurun. Menurut MartinPolo dkk. (1992), penggunaan lipid cair dalam formulasi film dapat membentuk struktur edible film yang lebih padat.

Interaksi perlakuan ekstrak gambir dengan minyak sawit seperti yang disajikan pada Tabel 2 menunjukkan bahwa kombinasi ekstrak gambir dengan konsentrasi tinggi dengan minyak sawit rendah menghasilkan yang memiliki persen pemajangan tinggi dan begitu juga sebaliknya. Hal ini menandakan bahwa peran masing-masing perlakuan sangat besar terhadap pembentukan karakteristik terutama pada persen pemanjangan.

Menurut Japanese International Standard (JIS) (1975) nilai persen pemanjangan edible film bioplastik minimal 70\%. Sedangkan hasil film plastik pada penelitian ini diperoleh nilai persen pemanjangan berada diatas nilai JIS. 
Berdasarkan hasil yang telah diperoleh tersebut maka hasil penelitian ini telah terjadi perbaikan persen pemanjangan.

\section{Laju Transmisi Uap Air}

Kemasan edible film bioplastik diharapkan mampu melindungi bahan makanan dengan menjaga oksigen dan kelembaban yang berada diluar kemasan. Sifat permeabilitas bioplastik terhadap gas dan uap air mampu melindungi produk yang dikemas dengan menjaga supaya oksigen dan uap air tetap berada diluar kemasan. Akan tetapi, pada kenyataannya edible film bioplastik tidak secara absolut mampu menahan gas dan uap air tersebut sehingga pada penelitian ini diharapkan dengan penambahan minyak kelapa sawit pada edible film berbasis pati sagu dapat menurunkan laju transmisi uap air.

Hubungan komposisi gambir dan minyak sawit terhadap laju transmisi uap air dapat dilihat pada Gambar 4.3

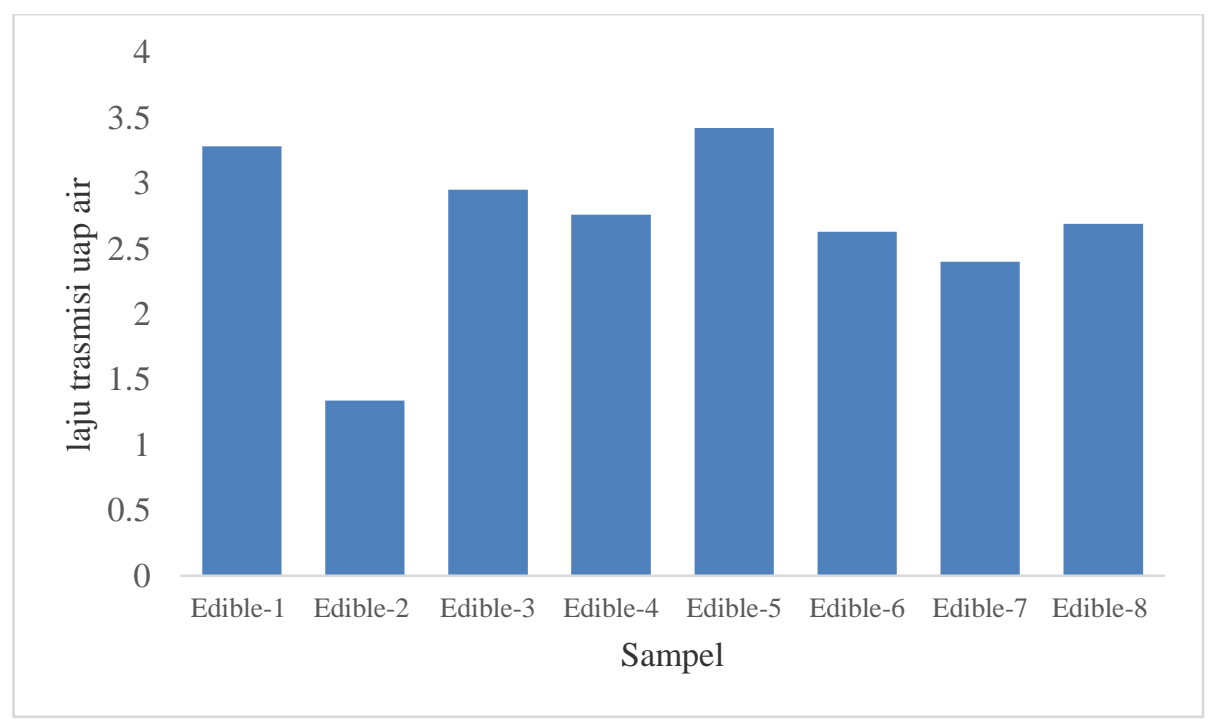

Gambar 3. Hubungan komposisi gambir dan minyak sawit terhadap laju transmisi uap air

Laju transmisi uap air yang dihasilkan memenuhi Japan International Standard (JIS) 1975 yaitu maksimal 10 g.m $\mathrm{m}^{-2}$.hari ${ }^{-1}$ seperti yang disajikan pada Gambar 4.3 Laju transmisi uap air terendah pada perlakuan Edible-2. Hal ini terjadi karena terbentuknya ikatan komplek matrik antara gambir-gliserol-minyak sawit. Asam lemak tidak jenuh dalam minyak sawit akan meregulasi asam-asam 
lemak dalam struktur matrik lebih merata dan padat, jika konsentrasi minyak sawit lebih tinggi maka makin banyak asam lemak tidak jenuh dalam struktur matrik yang tersebar merata. Asam lemak tidak jenuh bersifat hidropobik atau non polar, sehingga makin tinggi konsentrasi asam lemak tidak jenuh dalam matrik maka makin sulit uap air dapat menembus. Konsentrasi asam lemak mempunyai efek yang besar terhadap sifat penghambatan asam lemak yang ditambahkan sifat hidrofobiknya akan semakin besar sehingga laju transmisi uap airnya semakin menurun. Hal tersebut dikarenakan migrasi uap air umumnya hidrofobik bahan perlu diperhatikan untuk memperoleh nilai WVTR yang tepat (Garcia, 2000).

Laju transmisi uap air terendah pada penelitian ini sebesar $3,43 \mathrm{~g} \cdot \mathrm{m}^{-2}$ hari $^{-1}$ dan terbaik 1,34 g.m hari $^{-1}$ lebih rendah jika dibandingkan dengan hasil penelitian Santoso dkk. (2014) sebesar 4,18g. $\mathrm{m}^{-2} \cdot$ hari $^{-1}$. Perbandingan dari nilai laju transmisi uap air pada penelitian sebelumnya seperti data yang telah dijelaskan diatas maka hasil penelitian ini dapat disimpulkan bahwa laju trasmisi uap air yag diperoleh lebih baik, karena semakin rendah nilai laju transmisi uap air maka ketahanan edible film terhadap uap air semakin bagus

\section{Simpulan dan Saran}

\subsection{Kesimpulan}

Dari hasil penelitian yang telah dilakukan, maka dapat diambil kesimpulan sebagai berikut.

1. Gambir dan plasticizer gliserol berpengaruh terhadap sifat mekanik edible film yaitu uji kuat tarik dan persen pemanjangan yang diperoleh berada diatas nilai JIS.

2. Minyak sawit berpengaruh terhadap sifat laju transmisi uap air edilble film yaitu nilai laju transmisi uap air yang diperoleh dibawah nilai JIS.

\subsection{Saran}

Adapun saran yang diperoleh pada penelitian ini adalah sebagai berikut.

1. Diharapkan penelitian ini dapat dilanjutkan dengan melakukan analisa aktivitas antibakteri. 
2. Untuk penelitian berikutnya, disarankan saat pencetakan Edible film bioplastik ketebalan sampel disamakan.

\section{DAFTAR PUSTAKA}

1. Amaliya, dkk. 2014. Karakterisasi edible film daripati jagung dengan penambahan.

2. filtrat kunyit putih sebagai antibakteri. J. Pangan dan Agroindustri Vol.2 No.3.

3. American Society for Testing and Materials. (1997). Annual Book of ASTM Standards. Philadelphia, USA: ASTM.

4. Austin. 1985. Shercile's chemical process industries. Mc. Graw-hill book co: Tokyo.

5. Bourtoom, T. 2007. Effect of Some Process Parameters on The Properties of Edible Film Prepared From Starch. Department of Material Product Technology. Songkhala.

6. Dinas Perkebunan Sumatera Barat. 1998. Statistik perkebunan. Dinas Perkebunan Sumatera Barat, Padang.

7. Dwi, cindy herawati. 2015. Sintesa dan karakteristik edible film dari pati kulit pisang dengan penambahan lilin lebah (beeswax). Skipsi jurusan kimia fakultas matematika dan ilmu pengetahuan alam: universitas negeri semarang.

8. Guilbert, S. And B. Biquet. 1990. Edible films and coatings. In G. Bureau and J.L multon . food packaging. Vol 1 VCH Publisher. New york.

9. Haryanto, B dan Pangloli. 1992. Potensi dan Pemanfaatan Sagu. Yogyakarta : Kanisius

10. Hengky, N., 2003, Sagu Untuk Ketahanan Pangan, Pusat Penelitian dan Pengembangan Perkebunan, Manado

11. Hui, Y. H. 2006. Handbook of Food Science, Technology and Engineering. Volume 1, CRC Press: USA.

12. Johan, Alfredo,dkk. 2017. Pengaruh jenis dan konsentrasi plasticizer terhadap sifat fisik edible film kolang kaling (arenga pinnata). J. Pangan dan Agroindustri Vol.5 No.1:13-25.

13. Isnawati A, Raini M, Sampurno OD et al. 2012. Karakterisasi tiga jenis ekstrak gambir (Uncaria Gambir Roxb) dari Sumatera Barat. Buletin Penelitian Kesehatan 40(4): 201-208. 
14. Karouw, steivie, dkk. Karakteristik Biodegradable Film Pati Sagu dengan Penambahan Gliserol, CMC, Kalium Sorbat dan Minyak Kelapa. Buletin Palma Volume 18 No. 1, Juni 2017: 1 - 7.

15. Krochta, J. M. 1992. Edible Coating and Film to Improve Food Quality. Lancester: Tehnomic Publisher. Co. Inc.

16. Maulidia, ulfa. 2016. Pengaruh konsentrasi gliserol dan konsentrasi CMC terhadap karakteristik biodegradable film berbasis ampas rumput laut eucheuma cottonii. Skripsi jurusan Teknologi hasil pertanian Fakultas Teknologi Pertanian: universitas lampung.

17. Murdinah, dkk. 2007. Karakteristik edible film dari komposit alginat, gluten dan lilin lebah (beeswax). J. Pascapanen dan Bioteknologi Kelautan dan Perikanan Vol. 2 No. 1.

18. Purwani, E.Y. 2006. Mi Sagu : Perbaikan Mi Gleser dengan Sentuhan Teknologi. Balai Besar Penelitian dan Pengembangan Pascapanen Pertanian, Bogor.

19. Richana, N., S.widowati, dkk. 2000. Karakterisasi bahan berpati (tapioka, garut dan sagu) dan pemanfaatanya menjadi glukosa cair. Prosiding seminar nasional industri pangan vol. 1 surabaya, 10-11 oktober 2000. PATPI

20. Santoso, budi, dkk. 2016. Perbaikan sifat Fisik, Kimia, dan Antibakteri Edible Film Berbasis Pati Ganyong. J. Teknologi Hasil Pertanian. Vol. 36, No. 4

21. Vensia Novi M dan Joni Kusnadi. 2015. Antibakteri dari Ekstrak Kasar Daun Gambir (Uncaria Gambir Var Cubadak) Metode MicrowaveAssisted Extraction Terhadap Bakteri Patogen. J. Pangan dan Agroindustri Vol. 3 No 1.

22. Yulianti, rahmi dan Erliana Ginting. 2011. Perbedaan Katakteristik Fisik Edible Film dari Umbi-Umbian yang Dibuat dengan Penambahan Plasticizer. Jurnal Penelitian Pertanian Tanaman pangan., Vol.31., No.2.2012. 